\title{
Analysis of Needs to Basic Competence for BuildingConstruction Workers
}

\author{
Zulkifli Matondang $^{1 *}$, Syafiatun Siregar ${ }^{1}$, Sempurna Perangin-angin $^{1}$, Harun Sitompul ${ }^{1}$ \\ \{*zulkiflimato@gmail.com, zulmato@unimed.ac.id \} \\ ${ }^{1}$ Engineering Education Program, Faculty of Engineering, Universitas Negeri Medan, Indonesia
}

\begin{abstract}
Construction workers are people who are directly involved in the construction of a building. Construction workers generally do not have competence in the construction field. This happens because workers in the construction sector generally have a general education background. The purpose of this study is to analyze the basic competencies needed by construction workers. The research sample consisted of 45 construction workers in Medan. The instrument used was in the form of an assessment sheet with rating scale questionnaires. The data analysis was carried out using a descriptive and qualitative method. The results show: 1) The instrument's suitability test gives the average value of Aiken's V 0.87 ; 2) Construction workers need training to improve competence; 3) Basic skills needed by construction workers are: K3 implementation, material testing, equipment use, plastering work, tile/cramping installation, and mold installation. Tools and module are needed to improve the basic competencies of construction workers in the city of Medan.
\end{abstract}

Keywords: Basic competencies, construction workers, analysis of needs

\section{Introduction}

Construction work is an activity related to the construction of infrastructure or civil buildings [1]. The quality of construction workers plays an important role in achieving the goals and quality of buildings (projects). For that, construction workers need not have a higher education, but a specific competence or skill is necessary.

The policy on ASEAN economic community (MEA) has been implemented so that the formal job market is increasingly competitive [2]. The field of construction work requires high competitiveness, one of the conditions is the legality of education, which has an impact on the field of construction work in the city of Medan. Medan city statistical data shows the population with lower education than high school reached $32.23 \%$. The population of Medan is 2.5 million, with productive workers working in the informal sector at $57.50 \%$. The results of interviews with several contractors (building construction companies) in the city of Medan, stated that most of the workers in the building construction field had the highest education in senior high school. Generally, these workers, do not have expertise in the field of building construction. This causes construction workers to be less competent in carrying out work.

Based on these data, a research is necessary to analyze what competencies are needed by informal sector workers who can compete in the construction world. Construction work is a whole or part of a series of planning and/or implementation activities along with supervision that includes the respective architectural, civil, mechanical, electrical, environmental 
management work, and their completeness to realize a building or other physical form. In general, competence in the field of construction expertise, especially in buildings consists of several fields of work: concrete stone construction, steel construction, wood construction, building drawings, furniture, and so on. [3] Nanang D.A's research results (2010) stated that there were errors presented in presenting a building design, specifically for earthquake resistant buildings. The results of this study indicate that there is still a discrepancy between what is presented theoretically and what is done during the construction of a building. For this reason, efforts are needed so that a construction is constructed in accordance with the concept so that the building is in accordance with its function.

One area that absorbs a lot of labor in constructing a building is the construction of stone and concrete. The field of concrete stone expertise consists of a number of competencies: foundation installation, wall heating, stamping, floor work, finishing work, and others. The promising basic competencies in building construction are the finishing skill, for example, installation of ceramics, granite, natural stone, installation of molding, and wallpaper installation techniques. Workers skilled in finishing are still scarce in the job market. This will be the basis of this research: to provide basic competencies for building construction workers, especially in the field of finishing in concrete stone construction expertise. According to Caroline (2013), it is necessary to conduct basic competency training for students to improve competence before entering employment. Likewise, the basic competency training for building construction workers is expected to have an impact on increasing competency, competitiveness, and ultimately may improve the welfare of building construction workers. For this reason, it is necessary to plan an appropriate basic competency training for construction workers. This study emphasizes the analysis of the basic competencies needed by building construction workers.

\section{Methodology}

This research was conducted in the city of Medan. The research subjects were building construction workers, amounting to 45 people. This study aims to identify the basic competencies needed by construction workers in the field of building engineering. The data was obtained through an assessment sheet with a scale rating on basic competencies needed by construction workers. The validity test of the assessment sheet used is done with the Aiken's formula approach. The objective of this research is to increase the competence of construction workers in the building sector. For this reason, it is necessary to develop a training module in the field of building construction, which is intended for construction workers. Module development was based on the study by [4]. Data analysis techniques were carried out with a qualitative descriptive method. The main indicators of each aspect were done using assistance factor analysis in SPSS.

\section{Result and Discussion}

The results of observations and interviews with stakeholders in the field of construction in Medan shows that: a) the workers in the building construction field had competencies that needed to be improved, b) there are several types of competencies/skills needed by construction workers to make a building: foundation installation, wall installation, plastering, 
floor work, kozen installation work, door and window hanging work, ceiling installation work, roof installation work, sanitary installation work, and finishing work. Furthermore, from the results of the interviews, the most needed skills by workers is the expertise in concrete stonework. In addition, in carrying out the construction work, workers pay little attention to the occupational health and safety (OHS). This can be seen from construction workers who generally do not use the personal protective equipment (PPE) while working, such as not using shoes and hats. Moreover, the workplace does not provide the necessary aid and equipment.

The stages of analysis are: performance analysis and need analysis. Performance analysis is done to find out and identify whether the performance problems faced by workers require problem-solving in the form of training or management improvement. The implementation of construction work in the building sector has experienced problems, such as low skills/competency of workers, which results in the low performance of individuals in completing work. Improving the quality of knowledge and skills of workers needs to be done because of the low competency of construction workers in entering the building construction work. Therefore, it is necessary to conduct a needs analysis that is to determine the capabilities/competencies that need to be trained for workers to improve performance which has implications for increasing competence.

Needs analysis is carried out through an assessment sheet to stakeholders (users) of building construction, in this case, educators, practitioners, and instructors. The dissemination of this assessment sheet aims to obtain data on the need for the competence of construction workers. This assessment focused on the types of skills most needed by construction workers, especially in the field of concrete stonework. [5][6] suggest students should be equipped with basic competencies needed according to market needs. This is also necessary for students in the field of building construction. Workers in the field of building construction generally have a general education background, thus requiring training in basic competencies in the construction field. To find out the basic competencies needed by construction workers, an instrument was developed in the form of an assessment sheet. The assessment sheet was developed consisting of 47 questions with 6 aspects. Each question uses a Likert scale.

The results of the needs training data analysis are based on the assessment sheet using Aiken's formula. The results of the analysis are presented in Table 1.

\begin{tabular}{clccc}
\multicolumn{5}{c}{ Table 1. Training Needs Data Analysis Using V Aiken's } \\
\hline No. & \multicolumn{1}{c}{ Rated aspect } & $\begin{array}{c}\text { Number } \\
\text { of items }\end{array}$ & $\begin{array}{c}\text { V } \\
\text { Aiken's }\end{array}$ & $\begin{array}{l}\text { Infor } \\
\text { mation }\end{array}$ \\
\hline 1 & Healthy safety work & 9 & 0,906 & Valid \\
2 & Inspection of building materials & 12 & 0,906 & Valid \\
3 & Concrete Stone Work Tools & 13 & 0,888 & Valid \\
4 & Plastering Work & 5 & 0,877 & Valid \\
5 & Tile and Ceramic Installation & 3 & 0,890 & Valid \\
6 & Molding Techniques & 5 & 0,900 & Valid \\
\hline \multicolumn{2}{r}{ Summary } & 47 & 0,870 & Valid \\
\hline
\end{tabular}

Based on the results in Table 1, the average value of V Aiken's is 0.870 . The results of V Aiken's value analysis are at $0.870>0.600$ so it can be stated that the assessment sheet developed is in the valid category. This shows that, based on the data provided by construction workers, they really need training in all six aspects to be able to improve their knowledge and competence in the field of building construction. The 6 aspects needed by construction workers include: 1) Occupational Safety Health, 2) Building Material Inspection, 3) Concrete 
Stone Work Tools, 4) Plastering and Acian Work, 5) Tile and Ceramic Installation, and 6) Molding Technique.

Furthermore, based on the data provided, the average needs of construction workers for each aspect of concrete stonework are presented in Table 2.

Table 2. Validity Analysis Results of Concrete Stone Finishing Works

\begin{tabular}{|c|c|c|c|c|}
\hline No & Rated aspect & Average & Percent. & Note \\
\hline 1 & Healthy safety work & 4,622 & $92,44 \%$ & Very Needed \\
\hline 2 & Inspection of building materials & 4,550 & $91,00 \%$ & Very Needed \\
\hline 3 & Concrete Stone Work Tools & 4,508 & $90,15 \%$ & Very Needed \\
\hline 4 & Plastering Work & 4,560 & $91,20 \%$ & Very Needed \\
\hline 5 & Tile and Ceramic Installation & 4,600 & $92,00 \%$ & Very Needed \\
\hline 6 & Molding Techniques & 4,480 & $89,60 \%$ & Needed \\
\hline & Average & 4,553 & $91,07 \%$ & Very Needed \\
\hline
\end{tabular}

Based on the results of the needs analysis in Table 2, it can be concluded that every aspect of the concrete stonework is needed by construction workers to be trained on an average score of 91.07 (indispensable category). This shows that construction workers are in desperate need of training in improving their skills or competencies at work.

Based on the analysis of factors regarding occupational health and safety (OHS), out of 9 questions are categorized into two main factors, with an eigenvalue of $80.49 \%$. This means that two northern factors are able to explain $80.49 \%$ of the OHS. The first factor is formed by the indicators of tidying up the area and place of work as well as conducting first aid in case of accident. The second factor is formed by the indicator of the cause of the accident and the OHS law. The analysis result using factor analysis produces KMO and Bartlett's test values as Table 3.

Based on the results of calculations using SPSS, the KMO value is 0.854 , while the sig value is 0,000 calculated using Bartlett's Test. This shows that occupational safety health is important to be trained in building construction workers. For the building materials test material, based on the factor analysis result, there are 2 main factors with eigenvalue of $69.57 \%$, with details such as the following figure.

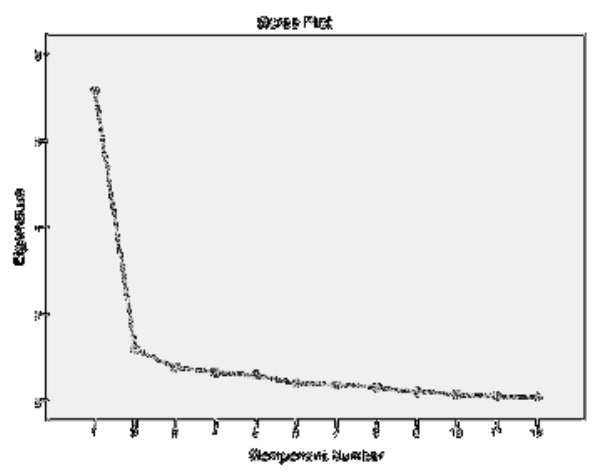

Fig. 1. Eigenvalue of Material Test

The first major factor is formed by the testing of aggregates (sand and gravel) and the removal of parts of the building, while the second main factor is formed by concrete testing. The KMO value is at 0.811 with a sig value of 0,000 from the results of Bartlett's test. This 
shows that the testing of building materials, which includes aggregate testing, testing of parts of a building, and concrete testing is needed for construction workers.

\begin{tabular}{llr}
\multicolumn{3}{c}{ Tabel 3. Hasil KMO and Bartlett's Test } \\
\hline $\begin{array}{l}\text { Kaiser-Meyer-Olkin Measure of } \\
\text { Sampling Adequacy. }\end{array}$ &, 854 \\
\hline $\begin{array}{l}\text { Bartlett's Test } \\
\text { of Sphericity }\end{array}$ & Approx. Chi-Square & 207,395 \\
\cline { 2 - 3 } & df & 36 \\
\cline { 2 - 3 } & Sig. &, 000 \\
\hline
\end{tabular}

For the aspects of concrete stone work equipment, of the 13-equipment filled with construction workers, there are two main factors. The first factor is stone and strand equipment, while the second factor is tool and jointer with eigenvalue of $74.30 \%$, $\mathrm{KMO}$ value of 0.762 , and sig value of 0,000 . Therefore, training for the use of equipment is also important to be given to construction workers, especially the use of concrete stone equipment, the use of strand, the use of concrete and jointer tools. In addition, the main factor that needs to be trained for the implementation of the plasterwork is how to install tiles and make concrete molds. Those are some of the basic competencies needed by construction workers, especially building construction, based on the results of the analysis.

\section{Conclusion}

The results of the analysis show that: 1) construction workers have low skills and the competency needs to be increased, especially in the field of concrete work, 2) the results of the instrument test gives an average value of Aiken's $\mathrm{V}$ of 0.870 , indicating that workers are in need of training to improve their skills/competencies. 3) the skills most needed by construction workers are: tidying up areas and workplaces, accidents aid, testing of aggregates (sand and gravel), testing of building construction parts, testing of concrete, use of equipment (strings, stone chisels), execution of plastering, tile/cramping installation, and concrete mold making.

\section{References}

[1] "Law Number 18 year 1999 concerning Construction Services."

[2] R. Thoriq, "Analisis Alternatigf Kebijakan Pemerintah Menghadapi Masyaraka Ekonomi ASEAN," 2015.

[3] H. Nanang D., "Miskonsepsi Tukang Bangunan Dalam Teknik Membangun Konstruksi Tahan gempa," J. Teras, vol. 10, no. 1, pp. 59-68, 2010.

[4] M. . Borg, W.R, \& Gall, Research Education: an instruction. New York: Longman Group, 1983.

[5] S. Purnomo, "Pembelajaran Berbasis Kompetensi," 2009. .

[6] B. T. Siswanto, Pendidikan Vokasi, Work-Based Learning, dan Penyelenggaraan Program Praktik Pengalaman Lapangan. Skripsi Fakultas Teknik Universitas Muhammadiyah Magelang: Workshop Penyusunan Buku Panduan Penulisan Laporan KP, 2013. 